\title{
Antiproliferative Potential of Ethyl acetate Extract of Clerodendrum thomsoniae Balf.f. on DMBA-induced Breast Cancer in Female Sprague-dawley Rats
}

\author{
VK Muhammed Ashraf ${ }^{1, *}$, VK Kalaichelvan ${ }^{1}$, R Ragunathan², VV Venkatachalam \\ ${ }^{1}$ Department of Pharmacy, Annamalai University, Annamalai Nagar, Tamil Nadu, INDIA \\ ${ }^{2}$ Centre for Bioscience and Nanoscience Research, Coimbatore, Tamil Nadu, INDIA.
}

\begin{abstract}
Background: Clerodendrum is a genus of around 500 species that has a place with the family Lamiaceae. Numerous types of this class have been demonstrated for the treatment of different maladies including cancer. This study aimed to investigate the anti-cancer activity of ethyl acetate fractions of Clerodendrum thomsoniae Balf.f. (EACT) in female Sprague-Dawley rats. Methods: 7, 12-dimethylbenz (a) anthracene (DMBA) was used to induce breast cancer. Two doses of $(25$ and $50 \mathrm{mg} / \mathrm{kg}$ ) EACT were used for the study. Various biochemical, hematological and, antioxidant parameters were analyzed. Results: Reduction in mean tumor volume and tumor weight was observed in EACT treated groups. The blood parameters were seen as normal. In both DMBA and doxorubicin groups, malondialdehyde were increased and the level was significantly reduced in EACT-treated groups. The effect of catalase has been seen as reduced in the groups administered by DMBA and doxorubicin and normal in the EACT groups. In the DMBA control groups, nitrate and nitrite were found to increase, the levels in others were normal. There were less necrosis and infiltration in breast tissues treated with doxorubicin as well as in EACT. The curative effect was found to be dose-dependent in animals treated with EACT. Some of the damaged breast patterns were restored to normal by the treatments. GC-MS analysis confirmed 2, 4-bis(1-phenylethyl)-phenol $(39 \%)$, which was found to be the major compound present in EACT. Conclusion: The study concludes that $C$. thomsoniae may be a potential anticancer candidate.
\end{abstract}

Key words: Clerodendrum thomsoniae Balf.f., 2, 4-bis(1-phenylethyl)-phenol, Breast cancer, EACT, Antiproliferative potential.

\section{INTRODUCTION}

Breast malignant growth is one of the most common and significant diseases among ladies, representing 25\% (1.7 million) of recent cases and $15 \%$ of cancer mortality. ${ }^{1}$ Breast cancer is described by extreme cell proliferation, wrong regulation of cellular differentiation and inadequate apoptosis. ${ }^{2}$ However, numerous studies in the last decade have shown that inflammation and angiogenesis are fundamental for primary cancer, including breast cancer, development, invasion and metastases. ${ }^{3-5}$ Chemically incited rat models of mammary malignancy have been widely utilized for many years to imitate human breast carcinogenesis. The mammary glands of a few rodent strains, predominantly Sprague-Dawley and Wistar rats are more sensitive chemical carcinogens and two most generally utilized breast cancer inducers are 7,12-dimethylbenz(a)anthracene (DMBA) and N-methylnitrosurea. ${ }^{6,7}$ The tumor incited by this model is morphologically and histologically like that saw in human estrogen-subordinate dependent breast cancer. ${ }^{8}$ Several markers for chemoprevention have been designed. These depend on the way that chemopreventive drugs can apply their anti-carcinogenic impacts by one or more combination mechanism such as hindering
Submission Date: 03-09-2020; Revision Date: 27-10-2020; Accepted Date: 20-01-2021

DOI: 10.5530/ijper.55.1.23 Correspondence: Mr. Muhammed Ashraf VK Department of Pharmacy, Annamalai University,

Chidambaram-608002, Tamil Nadu, INDIA.

Phone no: +919747313918 Email id: ashrafvkclt@gmail. com

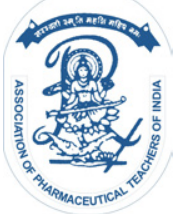

www.ijper.org 
the arrangement of reactive carcinogenic metabolites, promoting enzymes that detoxify cancer-causing agents, scavenging reactive oxygen species, affecting apoptosis and repressing cell proliferation. ${ }^{9,10}$

The earliest chemotherapy approach involves single alkylating and antimetabolite therapies which have now been replaced by combination treatment since it has been shown that two or more drugs have been used together for improved outcomes. ${ }^{11}$ The free radicals play a crucial function in the development of tumors through direct chemical reactions or modifications of cellular metabolic pathways and their scavengers can inhibit cancer cells at different phases of carcinogenesis. The toxicity of reactive oxygen (ROS), by the hindrance of ROS production, may be controlled by antioxidants. ${ }^{12}$ The modern management or treatment of breast cancer consists of surgery, chemotherapy and radiotherapy also hormone and anti-Her-2 therapies. ${ }^{13,14}$ Even though the immense alternatives of treatment and the innovations in breast malignancy treatment the remedial methodology at present still produces many reactions, which directly influence in the eminence of life and the accomplishment of the treatment. ${ }^{15}$ As a result, the search for remedies that could ease the side effects, alone or in combination with drugs previously consumed in breast cancer management, is a necessary step to upgrade the control of the disease.

Clerodendrum thomsoniae Balf.f. is a twined, rambling, wine-like shrub native to the tropical part of West Africa and the collective name is Bleeding-heart or Bag-flower. ${ }^{16,17}$ They have beautiful white flowers and are available in a different part of the world because of ornamental demand. These species are not extensively studied for pharmacological studies, even though many plants listed under genus Clerodendrum are well studied for various pharmacological studies including cancer. According to the data available, the species $C$. thomsoniae have phytoconstituents with excellent free radical scavenging properties and are useful in multiple conditions such as sores, cuts, bruises and skin rashes. ${ }^{18}$ The target of this study was to explore the anticancer activity of ethyl acetate fractions of $C$. thomsoniae (EACT) on female Sprague-Dawley rats using chemically induced (DMBA) breast cancer model.

\section{MATERIALS AND METHODS}

\section{Chemicals}

DMBA was supplied from Sigma Chemical Company St. Louis, MO, USA. All other chemical materials used in this study are of analytical quality, brought from Himedia Private Laboratories Ltd., Mumbai, India.

\section{Collection and identification of plant material}

Aerial parts of $C$. thomsoniae were obtained locally from Calicut district (Kerala, India). Department of Botany, University of Calicut (Calicut, India) identified the plant materials and authenticated them. Voucher specimens as specimen No.148249 were deposited in the same herbarium department.

\section{Selection of experimental animals}

Sprague-Dawley rats (Female, 125-175 g body weight) were used and kept in the animal house of the pharmacology department at K.M. College of Pharmacy, Tamil Nadu (India). The experiments were planned and executed in compliance with ethical standards approved by the Institutional Animal Ethical Committee (IAEC) of the same college under reference number IAEC/MUHAMMED ASHRAF VK/Ph.D/AU/ 1661130022/KMCP/91/2020. The selected rats were kept in plastic cages $\left(34 \times 47 \times 18 \mathrm{~cm}^{3}\right)$ at the institutional animal house, in a cooled situation with five mice in every cage and kept up at room temperature of $(25 \pm 2)^{\circ} \mathrm{C}$ with relative humidity $(60 \% \pm 10 \%)$ under $12 \mathrm{~h}$ light and dark cycle. All the animals were given easy access to standard food and water ad libitum and relocated to laboratory environments before the test.

\section{Preparation and extraction of the plant material}

The aerial parts of C. thomsoniae were dried appropriately in the shade for approximately three weeks, segregated, powdered by a mechanical grinder and, then passed through a 40 mesh sieve. About $1 \mathrm{~kg}$ of air-dried plant material was extracted with ethyl acetate in the soxhlet assembly. A rotary vacuum evaporator was used to concentrate the extract. Weighed the extract obtained and measured the percentage yield in terms of the dry weight of the plant material. The extract was also labeled with color and consistency. For this whole job, all solvents were of analytical rank (Merck, Mumbai).

\section{Fractionation of extract}

Column chromatography using Silica Gel (60-120 mesh size) was employed to fractionate ethyl acetate extracts. Fifty grams of the extract was submitted to flash chromatography utilizing silica gel (mesh size 60-120) as the stationary phase. The silica column was prepared using ethyl acetate by wet packing method and the column was washed using $100 \mathrm{ml}$ of ethyl acetate. For easy distribution of the sample, the ethyl acetate extract had been blended and made of fine powder with silica gel. On top of the pre-packed silica column, the powdered sample mass was loaded. The elution was performed by utilizing solvent polarity at increasing 
order made of hexane: ethyl acetate and methanol mixtures. Every $10 \mathrm{ml}$ of fractions were collected in vials and further analyzed by thin-layer chromatography. Seven identical fractions (F1-F7) have been mixed, evaporated to dryness and kept in the dark for further analysis. All fractions were tested for cytotoxicity by MT'T assay by means of MCF-7 (human breast cancer cell line) and fraction 5 (F5) showed better cytotoxicity and hence the same fractions were used for this studies.

\section{GC-MS analysis}

Perkin Elmer GC-MS (Model- Perkin Elmer Clarus 500, United States) was selected for the GC-MS study. The analysis was done according to the manufacturer's guidelines. The mass spectrum of GC-MS was interpreted by the National Institute of Standard and Technology (NIST-Version 14) database as well as the WILEY 8 library. The percentage of every component was calculated from the relative peak area of every element in the chromatogram. The name, molecular weight, peak area and retention time of the compounds present has been determined.

\section{Tumor induction and drug treatment}

The DMBA is a powerful carcinogenic agent and is used to induce tumors in animals. A single dose of the same (30 mg/kg) was given orally to respective groups with the aid of an intragastric tube. Tumors were developed after 14 weeks. The test sample EACT $25 \mathrm{mg} / \mathrm{kg}$ and EACT $50 \mathrm{mg} / \mathrm{kg}$ were administered orally for duration of four weeks. Rats selected for the study were fasted overnight and sacrificed toward the completion of the investigation. For further biochemical studies, the blood was extracted and the serum was isolated.

\section{Experimental design}

Previously reported methods were executed for the animal experiments and evaluation of different parameters. ${ }^{19}$ Animals are grouped and treatment was given as follows,

- Group I: $0.25 \%$ of carboxymethyl cellulose (CMC) was received orally and is considered as normal control

- Group II: Mammary tumor induced rats by DMBA.

- Group III: DMBA administered mammary tumor groups. Animals are treated with doxorubicin once weekly for 4 weeks $(2 \mathrm{mg} / \mathrm{kg}$, i.p)

- Groups IV and V: DMBA administered rats treated with EACT $25 \mathrm{mg} / \mathrm{kg}$ and EACT $50 \mathrm{mg} /$ $\mathrm{kg}$ respectively for 4 weeks (suspended at $0.25 \%$ CMC) p.o.
Drug administration began when tumors became stable and clearly palpable.

\section{General observations}

Throughout the experiment, the total changes in body weight in the animals were recorded every week. Rats were sacrificed after the study, dissected and weighed vital organs viz. liver, kidneys, spleen and heart.

\section{Tumor weight and tumor volume}

Vernier calipers were used to assess tumors, ${ }^{20}$ and the volume of tumors was measured as follows,

The volume of tumor $=\left(\mathrm{L} \times \mathrm{W}^{2}\right) / 2$, where $\mathrm{L}$ and W deliberated as length and width in centimeter, respectively.

\section{Hematological parameters}

Blood from the animals retro-orbital plexus and measured by the help of a veterinary blood cell counter.

\section{Antioxidant and biochemical evaluation in breast tissue}

Breast tissues were removed and blood was wiped, blotted and gauged with super cold PBS. In potassium chloride solution $(1.15 \% \mathrm{w} / \mathrm{v})$ tissue homogenate has been prepared $(10 \% \mathrm{w} / \mathrm{v})$. To get a clear supernatant used to estimate anti-oxidant and biochemical parameters, the homogenate obtained was centrifuged for $10 \mathrm{~min}$ at $8000 \mathrm{rpm}\left(4^{\circ} \mathrm{C}\right)$.

\section{Assessment of nitric oxide (NO)}

Breast tissue nitrogen oxide levels were assessed by measuring the cumulative concentrations of nitrate and nitrite. The Griess reagent method was used to estimate the nitrite content. At $37^{\circ} \mathrm{C}$ for $20 \mathrm{~min}$, the Griess reagent $(100 \mu \mathrm{L})$ and of the homogenous tissue $(100 \mu \mathrm{L})$ were incubated, The absorbance was measured at $540 \mathrm{~nm}$ and nitrite content was derived from a standard curve of sodium nitrite. ${ }^{21} 100 \mu \mathrm{L}$ of homogenate from breast tissue was incubated at $45^{\circ} \mathrm{C}$ for $60 \mathrm{~min}$ with Griess reagent and vanadium (III) chloride. A micro plate reader was employed to measure absorbance at $540 \mathrm{~nm}$.

\section{Lipid peroxidation analysis}

The breast tissue homogenate $(200 \mu \mathrm{L})$ was treated with $8.1 \%$ of sodium dodecyl sulphate $(200 \mu \mathrm{L}), 20$ $\%$ of acetic acid $(1.5 \mathrm{ml})$ solution and $0.8 \%$ aqueous thiobarbituric acid solution $(1.5 \mathrm{~mL})$.the total volume is then made up to $4 \mathrm{ml}$ with distilled water and then heated for $1 \mathrm{~h}$ at $95^{\circ} \mathrm{C}$. Distilled water $(1 \mathrm{ml})$, n-butanol $(5 \mathrm{ml})$ and pyridine mixture were added to the cooled mixture. The mixture was shaken strongly and then 
centrifuged for $5 \mathrm{~min}$ at $5000 \mathrm{rpm}$ speed. The top layer was discarded and UV spectrophotometer was used to measure the absorbance at $532 \mathrm{~nm} .{ }^{22}$

\section{Assessment of catalase level}

For the assessment of catalase level,,$^{23}$ the breast tissue homogenate was then added to $3 \mathrm{ml}$ of hydrogen peroxide solution $(0.036 \% \mathrm{w} / \mathrm{w})$. The absorbance was documented at $240 \mathrm{~nm}$.

\section{Assessment of serum biomarkers}

Appropriate auto analyzer kits (Roche Diagnostics, Indianapolis, USA) were employed for the assessment of Creatinine, Alanine transaminase (ALT), Urea and Aspartate aminotransferase (AST).

\section{Histopathological evaluation of breast tissues}

Tissues have been fixed in neutral buffered formalin $(10 \%)$, washed with alcohol and cleared with xylene to help the histopathological assessment of the breast. Paraffin wax impregnated tissue and $5 \mu \mathrm{m}$ section were then fixed on the slides and dewaxed with the help of xylene and rehydrated by using alcohol by means of a rotating microtome (RM22545, Leica Microsystems $\mathrm{GmbH}$, Wetzlar). Hematoxylin and eosin were then stained to the tissues. The slides were monitored and

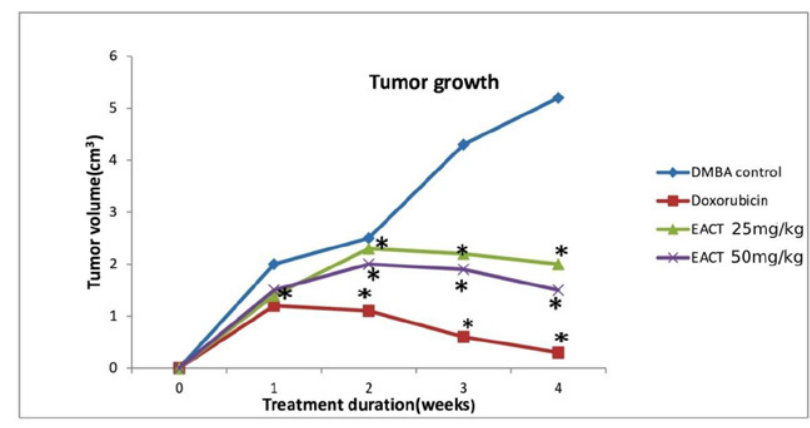

Figure 1: Influence of EACT and Doxorubicin on tumor development. The drug treatments were continued for four weeks period. All treatments began after the tumor growth was palpable and the start of drug treatment was measured as $0^{\text {th }}$ week. All values are expressed as mean \pm SEM; ${ }^{*} p<0.05$ compared to DMBA Control; $n=6$. interpreted by an expert (pathologist) under a microscope to identify the type of carcinoma, immune cell infiltration, necrosis and hemorrhage in the tubular alveolar pattern.

\section{Statistical analysis}

The one-way variance analysis (ANOVA), followed by "Tukey's post hoc test" by GraphPad Prism 6.05 version was used for evaluating statistical comparisons and significance. Two-way ANOVA followed by "Tukey's post hoc test" was utilized to examine the effect on tumor growth. All results were presented as Mean \pm SEM, The significance value of $p<0.05$ was considered.

\section{RESULTS}

\section{Treatment impact on organ weight and body mass}

The weight of the liver, heart and kidneys between treatment and control groups was not significantly changed. Although the mass of spleen was notability decreased in the doxorubicin administered groups when contrasted with DMBA control and normal control groups. There was no remarkable variation in body weight additionally seen among all groups (Table 1).

\section{Treatment impact on tumor growth and the weight of tumors}

The impression of the treatment on tumor progression was measured by evaluating the volume of tumor reliably (every week). Along these lines, the rats were sacrificed; the parameters such as mean tumor weight and mean tumor volume was observed. Doxorubicin diminished the tumor volume significantly following one week of treatment. All animals treated with EACT at both doses significantly decreased the mean tumor volume and the mean tumor weight when compared to control rats treated with DMBA alone (Figure 1 and 2). The rats treated with EACT $25 \mathrm{mg} / \mathrm{kg}$ and EACT $50 \mathrm{mg} / \mathrm{kg}$ diminished the volume of tumor after 3 weeks of the EACT treatment when matched to the DMBA control groups significantly. The most significant decrease in tumor volume was seen in the fourth week.

\section{Table 1: Impact of the treatments in Sprague Dawley rats on body weight and organ weight.}

\begin{tabular}{|c|c|c|c|c|c|}
\hline Groups & $\begin{array}{c}\text { Heart } \\
\mathbf{( g )}\end{array}$ & $\begin{array}{c}\text { Spleen } \\
\mathbf{( g )}\end{array}$ & $\begin{array}{c}\text { Kidney } \\
\mathbf{( g )}\end{array}$ & $\begin{array}{c}\text { Liver } \\
\mathbf{( g )}\end{array}$ & $\begin{array}{c}\text { Growth in } \\
\text { body weight } \mathbf{( \% )}\end{array}$ \\
\hline Normal Control & $0.85 \pm 0.77$ & $0.74 \pm 0.64$ & $0.77 \pm 0.32$ & $5.23 \pm 0.32$ & $116.67 \pm 5.76$ \\
\hline DMBA control & $0.81 \pm 0.28$ & $0.77 \pm 0.33$ & $0.73 \pm 0.23$ & $5.45 \pm 0.23$ & $126.32 \pm 5.22$ \\
\hline Doxorubicin & $0.78 \pm 0.67$ & $0.34 \pm 0.45^{\mathrm{a}, \mathrm{b}}$ & $0.78 \pm 0.34$ & $5.34 \pm 0.24$ & $117.78 \pm 5.82$ \\
\hline EACT 25mg/kg & $0.85 \pm 0.45$ & $0.71 \pm 0.24$ & $0.72 \pm 0.42$ & $5.21 \pm 0.45$ & $125.34 \pm 5.12$ \\
\hline EACT 50mg/kg & $0.89 \pm 0.53$ & $0.72 \pm 0.42$ & $0.75 \pm 0.34$ & $5.45 \pm 0.31$ & $119.23 \pm 4.75$ \\
\hline
\end{tabular}

All the values are measured in mean $\pm \mathrm{SEM}_{i}{ }^{\mathrm{a}} p<0.05$ compared to normal control groups;

${ }^{\mathrm{b}} p<0.05$ compare to DMBA Control; $\mathrm{n}=6$. 


\section{Impact of treatment on blood parameters}

The Red blood cell counts (RBC) and the level of hemoglobin were diminished in doxorubicin administered groups significantly when contrasted with normal control. It may be a clear result of doxorubicin's bone marrow toxicity. EACT both doses not produced any significant changes in any blood parameters (Table 2).

\section{Impact on catalase levels and lipid peroxidation in breast tissue}

In the DMBA and doxorubicin treated animal groups, the catalase activity in breast tissue was significantly reduced when compared to the normal control. Compared with normal control, however, the EACT treated animal groups, the catalase activity was not significant. The level of Malondialdehyde (MDA) was significantly enhanced in both doxorubicin and DMBA control-treated rats when compared with normal control animals. The difference in MDA levels in EACT treated groups at both doses does not produce any significant changes when compared to normal control groups (Table 3).

\section{Treatment impacts biochemical parameters}

In both DMBA control and doxorubicin-treated group aspartate transaminase (AST) were increased compared

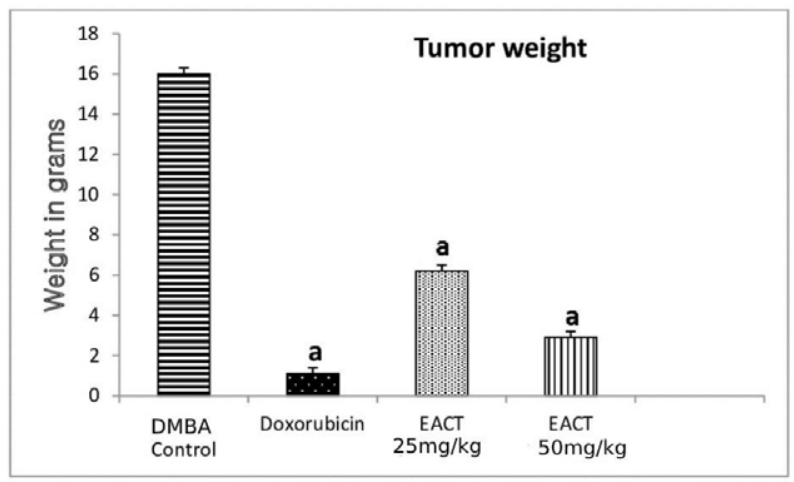

Figure 2: Influence of the treatments on mean tumor weight; All the values are given as mean $\pm \mathrm{SEM} ;{ }^{\mathrm{a}} p<0.05$ compared to DMBA Control; $n=6$. to the normal group, but in the EACT-treated group, the level was normal. This can be attributed to DMBA and doxorubicin's toxic effect on the liver. The urea level was significantly increased compared with normal control groups, in both DMBA and doxorubicin treatment groups. The urea level was, however, almost normal in EACT groups. The levels of alanine aminotransferase (ALT) and creatinine were not significantly altered in any groups (Table 4).

\section{Treatment impact on levels of nitrate and nitrite in breast tissue}

In the control group treated with DMBA, the levels of nitrate and nitrites were enhanced and oxidative stress was shown. The levels for all other treatment groups were near normal (Figure 3).

\section{Histopathology studies on breast tissue}

Sections of breast tissue from the DMBA control tumor groups showed tissue infiltrated in lobules, plentiful fibrous stroma and proliferated ductules.

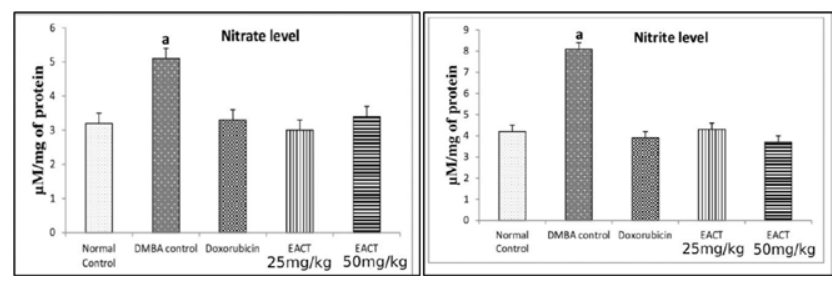

Figure 3: Treatment impact on nitrate, nitrite levels in the breast tissue. All the values are expressed as mean \pm SEM; a $p<0.05$ compared to Normal control; $n=6$.

Table 3: Treatment impact on catalase levels and lipid peroxidation on breast tissue.

\begin{tabular}{|c|c|c|}
\hline Groups & $\begin{array}{c}\text { Catalase } \\
\text { (U/mg of protein) }\end{array}$ & $\begin{array}{c}\text { MDA } \\
\text { (mM/100g of tissue) }\end{array}$ \\
\hline Normal Control & $43.36 \pm 1.42$ & $1.08 \pm 0.21$ \\
\hline DMBA control & $24.47 \pm 1.75^{\mathrm{a}}$ & $2.52 \pm 0.86^{\mathrm{a}}$ \\
\hline Doxorubicin & $24.03 \pm 1.32^{\mathrm{a}}$ & $2.79 \pm 0.48^{\mathrm{a}}$ \\
\hline EACT $25 \mathrm{mg} / \mathrm{kg}$ & $42.24 \pm 1.25^{\mathrm{b}}$ & $0.78 \pm 0.52^{\mathrm{b}}$ \\
\hline EACT $50 \mathrm{mg} / \mathrm{kg}$ & $44.35 \pm 1.84^{\mathrm{b}}$ & $0.97 \pm 0.35^{\mathrm{b}}$ \\
\hline
\end{tabular}

All the values are given as mean $\pm \mathrm{SEM} ;{ }^{\mathrm{a}} p<0.05$ compared to normal control; ${ }^{\mathrm{b}} p<0.05$ compared to DMBA control; $n=6$.

Table 2: Impact of treatments in Sprague Dawley rats on blood parameters.

\begin{tabular}{|c|c|c|c|c|}
\hline \multicolumn{5}{|c|}{ Table 2: Impact of treatments in Sprague Dawley rats on blood parameters. } \\
\hline Groups & RBC $(\times \mathbf{1 0} / \boldsymbol{\mu l})$ & WBC $\left(\times 10^{3} / \mu \mathbf{l}\right)$ & Platelets $\left(\times 10^{3} / \mu \mathbf{l}\right)$ & Hb (g/dl) \\
\hline Normal Control. & $8.35 \pm 0.32$ & $12.45 \pm 0.24$ & $417 \pm 19.37$ & $12.23 \pm 0.76$ \\
\hline DMBA control & $7.76 \pm 0.54$ & $11.53 \pm 0.38$ & $465 \pm 23.76$ & $11.53 \pm 0.56$ \\
\hline Doxorubicin & $5.44 \pm 0.74^{\mathrm{a}}$ & $11.64 \pm 0.54$ & $417 \pm 14.56$ & $8.54 \pm 0.34^{\mathrm{a}}$ \\
\hline EACT 25mg/kg & $8.65 \pm 0.43$ & $11.54 \pm 0.85$ & $489 \pm 23.54$ & $12.32 \pm 0.84$ \\
\hline EACT 50mg/kg & $7.78 \pm 0.28$ & $12.17 \pm 0.45$ & $453 \pm 17.72$ & $12.13 \pm 0.58$ \\
\hline
\end{tabular}

All the values given as mean $\pm \mathrm{SEM}^{\mathrm{a}} \mathrm{p}<0.05$ compared to normal control; $n=6$. 
Table 4: The impacts of treatments in Sprague Dawley rats on serum biochemical parameters.

\begin{tabular}{|c|c|c|c|c|}
\hline Groups & Urea $(\mathbf{m g} / \mathbf{d L})$ & Creatinine $(\mu \mathrm{mol} / \mathrm{L})$ & AST (U/L) & ALT (U/L) \\
\hline Normal Control & $27.83 \pm 0.64$ & $31.24 \pm 0.32$ & $127.83 \pm 2.22^{\mathrm{a}}$ & $63.34 \pm 0.34$ \\
\hline DMBA control & $35.13 \pm 0.39$ & $30.34 \pm 0.42$ & $153.36 \pm 1.63^{\mathrm{a}}$ & $62.76 \pm 0.32$ \\
\hline Doxorubicin & $33.25 \pm 0.25$ & $30.15 \pm 0.25$ & $159.63 \pm 2.25^{\mathrm{a}}$ & $60.34 \pm 1.73$ \\
\hline EACT 25mg/kg & $28.35 \pm 0.53$ & $31.32 \pm 0.42$ & $129.34 \pm 2.64^{\mathrm{a}}$ & $63.84 \pm 0.32$ \\
\hline EACT 50mg/kg & $27.14 \pm 0.37$ & $30.43 \pm 0.94$ & $130.35 \pm 1.42^{\mathrm{a}}$ & $64.97 \pm 0.45$ \\
\hline
\end{tabular}

All the values are given as mean $\pm \mathrm{SEM}$; a $p<0.05$ compared to Normal control; $n=6$.

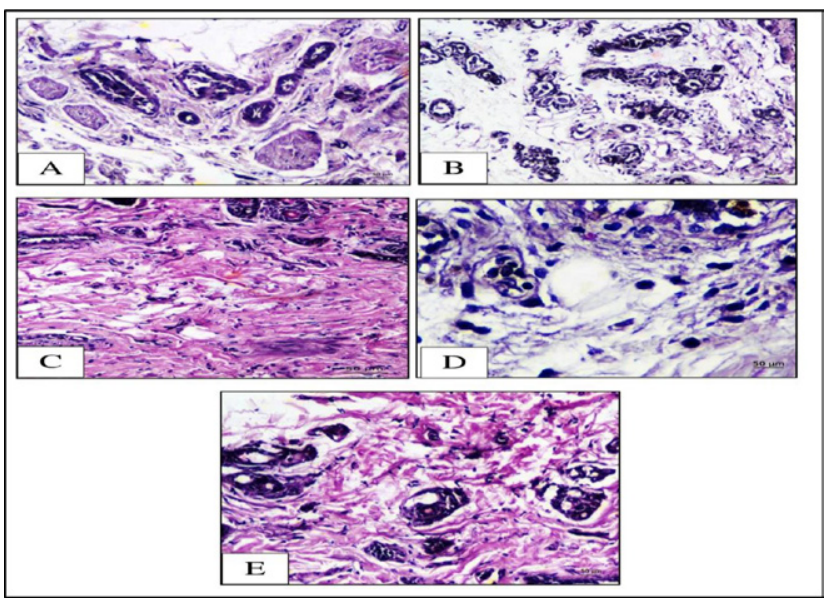

Figure 4: Breast tissues histopathology: A- Normal control animals, B,C,D and E denotes DMBA control ,doxorubicin, EACT $25 \mathrm{mg} / \mathrm{kg}$ and EACT $50 \mathrm{mg} / \mathrm{kg}$ treated groups respectively (observed under 40x).

Necrosis were also recognized in large area. This typical features designated as invasive ductal carcinoma. The breast tissues collected from the rats treated with doxorubicin showed fewer necrosis and infiltration; similarly, the tested sample EACT $25 \mathrm{mg} / \mathrm{kg}$ and EACT $50 \mathrm{mg} / \mathrm{kg}$ also showed less necrosis and infiltration. The treatments were able to refurbish some of the damaged breast patterns to normal (Figure 4).

\section{GC-MS analysis}

The GC-MS analysis was conducted for fraction F5 which was the most active fraction of ethyl acetate extract tested in this experiment (Figure 5). A mass spectrometry attached to GC has identified the compound present. The compounds were determined by molecular weight, molecular formula, peak area and retention time (Table 4). The presence of several compounds in fraction F5 has been demonstrated by the GC-MS analysis and the compound 2, 4-bis(1-phenylethyl)phenol $(39 \%)$ was found to be major. The other important compound present are ethyl 4-(ethyloxy)-2oxobut-3-enoate $(5.25 \%)$, ethenyl-benzene also known as styrene (4.33\%) and 2-(1-phenylethyl)phenol (3.37\%).

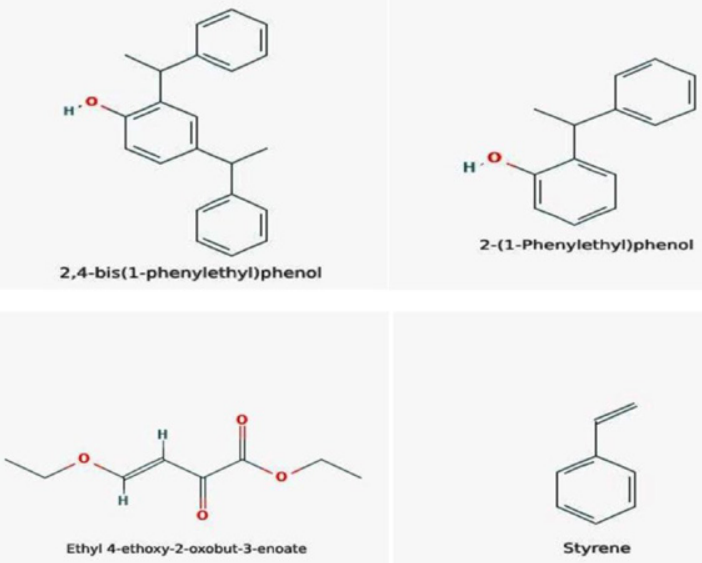

Figure 5: Structure of significant compounds identified in fraction F5 of Clerodendrum thomsoniae Balf.f.

\section{DISCUSSION}

Universally Breast cancer is a common neoplasm among females and has great level of occurrence of mortality. ${ }^{24}$ Currently, breast cancer managements consist of surgery, chemo medications, radiation therapy, hormone and immunotherapy; though these remedies have many toxic effects. ${ }^{25}$ Herbal products are used and examined to identify and enhance therapeutic anticancer agents. Experimental procedures using animal systems are predominantly beneficial for the learning of human mammary carcinogenesis. In our investigation, a single dose $(30 \mathrm{mg} / \mathrm{kg})$ of 7,12 -dimethylbenz (a) anthracenes (DMBA) prepared in olive oil through an intragastric tube was used to induce tumor. Human breast malignant growth typically starts in the ductal district and the DMBA-induced mammary tumor model shows similar inception. ${ }^{26}$ DMBA-instigated carcinogenesis had been recorded to be related with ductal carcinoma, fibro adenoma and papilloma. ${ }^{27}$ In human breast carcinomas, multiplication happens solely in epithelial cells. ${ }^{28-30}$ The rat model is therefore a valuable animal model for human breast cancer. The rat mammalian glans then have a good chance of 
Table 4: Phytocompounds identified in the fraction F5 of Clerodendrum thomsoniae Balf.f. by GC-MS analysis.

\begin{tabular}{|c|c|c|c|c|c|}
\hline S.No & RT (min) & Compounds Name & Area \% & MW & MF \\
\hline 1 & 4.082 & 1,1-diethoxy-2-methyl propane & 0.33 & 146 & $\mathrm{C}_{8} \mathrm{H}_{18} \mathrm{O}_{2}$ \\
\hline 2 & 4.409 & 1-butanol,3-methyl-,acetate & 1.55 & 130 & $\mathrm{C}_{7} \mathrm{H}_{14} \mathrm{O}_{2}$ \\
\hline 3 & 4.709 & ethenyl-benzene, & 4.33 & 104 & $\mathrm{C}_{8} \mathrm{H}_{8}$ \\
\hline 4 & 4.993 & cyclobutanone-3-d,2,2-dimethyl-,(s) - & 0.46 & 99 & $\mathrm{C}_{6} \mathrm{H}_{9} \mathrm{DO}$ \\
\hline 5 & 5.104 & ethyl 4- (ethyloxy) -2-oxobut-3-enoate & 5.25 & 172 & $\mathrm{C}_{8} \mathrm{H}_{12} \mathrm{O}_{4}$ \\
\hline 6 & 5.8 & 1,1-diethoxy-3-methyl-butane, & 0.44 & 160 & $\mathrm{C}_{9} \mathrm{H}_{20} \mathrm{O}_{2}$ \\
\hline 7 & 6.759 & benzene,1,2,3-trimethyl- & 1.85 & 120 & $\mathrm{C}_{9} \mathrm{H}_{12}$ \\
\hline 8 & 11.342 & 1-heptadecanol & 0.52 & 256 & $\mathrm{C}_{17} \mathrm{H}_{36} \mathrm{O}$ \\
\hline 9 & 12.51 & (z) -1- (methoxymethoxy) -2-methyl-2-pentene & 0.63 & 144 & $\mathrm{C}_{8} \mathrm{H}_{16} \mathrm{O}_{2}$ \\
\hline 10 & 15.343 & eicosyl acetate & 0.28 & 340 & $\mathrm{C}_{22} \mathrm{H}_{44} \mathrm{O}_{2}$ \\
\hline 11 & 15.916 & 1-undecanol & 2.32 & 172 & $\mathrm{C}_{11} \mathrm{H}_{24} \mathrm{O}$ \\
\hline 12 & 16.093 & pentadecane & 0.25 & 212 & $\mathrm{C}_{15} \mathrm{H}_{32}$ \\
\hline 13 & 17.159 & 3-deuterio-1-methylpyrazole & 0.38 & 83 & $\mathrm{C}_{4} \mathrm{H}_{5} \mathrm{DN}_{2}$ \\
\hline 14 & 17.325 & 2,2,7,7-tetramethyl-3,6-octanedione & 0.46 & 198 & $\mathrm{C}_{12} \mathrm{H}_{22} \mathrm{O}_{2}$ \\
\hline 15 & 19.953 & 3- (o-azidophenyl) propanol & 0.53 & 177 & $\mathrm{C}_{9} \mathrm{H}_{11} \mathrm{~N}_{3} \mathrm{O}$ \\
\hline 16 & 20.058 & 1-hexadecanol & 3.75 & 242 & $\mathrm{C}_{16} \mathrm{H}_{34} \mathrm{O}$ \\
\hline 17 & 20.205 & 5-methyl-undecane, & 0.43 & 170 & $\mathrm{C}_{12} \mathrm{H}_{26}$ \\
\hline 18 & 22.102 & pentadecane & 0.38 & 212 & $\mathrm{C}_{1} \mathrm{H}_{32}$ \\
\hline 19 & 22.465 & 2- (1-phenylethyl) -phenol, & 3.37 & 198 & $\mathrm{C}_{14} \mathrm{H}_{14} \mathrm{O}$ \\
\hline 20 & 23.662 & 3-ethyl-2-pentanol, & 0.25 & 116 & $\mathrm{C}_{7} \mathrm{H}_{16} \mathrm{O}$ \\
\hline 21 & 23.785 & 1-nonadecene & 4.54 & 266 & $\mathrm{C}_{19} \mathrm{H}_{38}$ \\
\hline 22 & 23.909 & docosane & 0.74 & 310 & $\mathrm{C}_{22} \mathrm{H}_{46}$ \\
\hline 23 & 25.16 & 9-heptadecanone & 1.3 & 254 & $\mathrm{C}_{17} \mathrm{H}_{340}$ \\
\hline 24 & 26.29 & 1-iodo-nonane, & 0.9 & 254 & $\mathrm{C}_{9} \mathrm{H}_{19} \mathrm{I}$ \\
\hline 25 & 26.507 & dibutyl phthalate & 7.16 & 278 & $\mathrm{C}_{16} \mathrm{H}_{22} \mathrm{O}_{4}$ \\
\hline 26 & 27.05 & 2,3-dimethyl-hexane, & 0.52 & 688 & $\mathrm{C}_{8} \mathrm{H}_{18}$ \\
\hline 27 & 27.163 & 1-nonadecene & 3.86 & 266 & $\mathrm{C}_{19} \mathrm{H}_{38}$ \\
\hline 28 & 27.272 & 1-bromo-8-methylhexacosane & 0.95 & 458 & $\mathrm{C}_{27} \mathrm{H}_{5} \mathrm{Br}$ \\
\hline 29 & 28.835 & 1- (2-hydroxyethoxy) tridecane & 1.07 & 244 & $\mathrm{C}_{15} \mathrm{H}_{32} \mathrm{O}_{2}$ \\
\hline 30 & 28.944 & 1,4-butanediol,2,3-diethyl-2,3-dimethyl-, & 1.48 & 174 & $\mathrm{C}_{10} \mathrm{H}_{22} \mathrm{O}_{2}$ \\
\hline 31 & 29.133 & 1,4-butanediol,2,3-diethyl-2,3-dimethyl-, & 0.39 & 174 & $\mathrm{C}_{10} \mathrm{H}_{22} \mathrm{O}_{2}$ \\
\hline 32 & 29.22 & decanoic acid,8-methyl-,methyl ester & 0.35 & 200 & $\mathrm{C}_{12} \mathrm{H}_{24} \mathrm{O}_{2}$ \\
\hline 33 & 30.163 & 2-heptene-1,7-dial & 0.67 & 126 & $\mathrm{C}_{7} \mathrm{H}_{10} \mathrm{O}_{2}$ \\
\hline 34 & 30.248 & (trans) -2-nonadecene & 1.91 & 266 & $\mathrm{C}_{19} \mathrm{H}_{38}$ \\
\hline 35 & 30.334 & 1-bromo-8-methylhexacosane & 0.64 & 458 & $\mathrm{C}_{27} \mathrm{H}_{55} \mathrm{Br}$ \\
\hline 36 & 30.442 & 1-octadecene & 1.01 & 252 & $\mathrm{C}_{18} \mathrm{H}_{36}$ \\
\hline 37 & 31.865 & 2,3,3-trimethyl-pentane, & 1.17 & 114 & $\mathrm{C}_{8} \mathrm{H}_{18}$ \\
\hline 38 & 32.987 & hexanedioic acid,bis (2-ethylhexyl) ester & 1.07 & 370 & $\mathrm{C}_{22} \mathrm{H}_{42} \mathrm{O}_{4}$ \\
\hline 39 & 33.084 & 1,7-dimethyl-4- (1-methylethyl) cyclodecane & 0.9 & 210 & $\mathrm{C}_{15} \mathrm{H}_{30}$ \\
\hline 40 & 33.189 & 2,4-bis (1-phenylethyl) -phenol & 11.12 & 302 & $\mathrm{C}_{22} \mathrm{H}_{22} \mathrm{O}$ \\
\hline 41 & 33.414 & 2,4-bis (1-phenylethyl) -phenol & 9.54 & 302 & $\mathrm{C}_{22} \mathrm{H}_{22} \mathrm{O}$ \\
\hline 42 & 34.187 & 2,4-bis (1-phenylethyl) -phenol & 18.4 & 302 & $\mathrm{C}_{22} \mathrm{H}_{22} \mathrm{O}$ \\
\hline 43 & 34.864 & Di isooctyl-phthalate & 1.77 & 390 & $\mathrm{C}_{24} \mathrm{H}_{38} \mathrm{O}_{4}$ \\
\hline 44 & 37.483 & 4-methylhept-3-yl propyl ester phthalicacid, & 0.24 & 320 & $\mathrm{C}_{19} \mathrm{H}_{28} \mathrm{O}_{4}$ \\
\hline 45 & 39.365 & 1,4-butanediol, & 0.51 & 114 & $\mathrm{C}_{6} \mathrm{H}_{10} \mathrm{O}_{2}$ \\
\hline
\end{tabular}

$\mathrm{MW}=$ molecular weight $; \mathrm{RT}=$ retention time; $\mathrm{MF}=$ molecular formula 


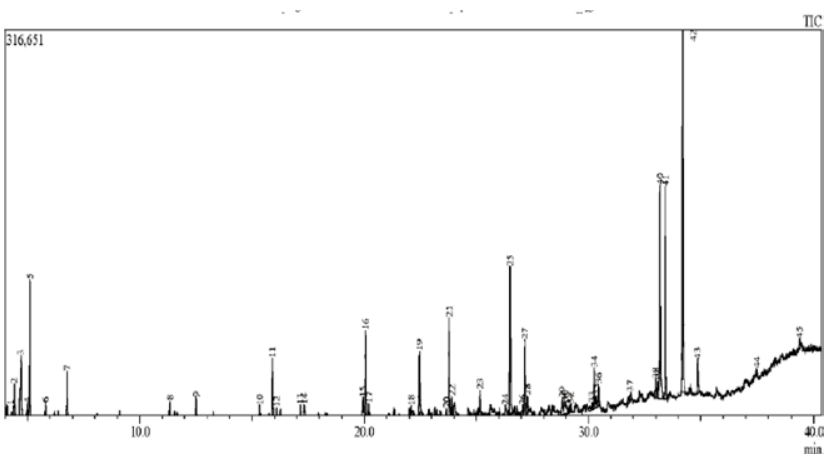

Figure 6: GC-MS chromatogram of Fraction 5 (F5) of Clerodendrum thomsoniae Balf.f. is given at Figure 6.

developing neoplasms which closely imitate human breast cancer. ${ }^{31}$ The harmfulness of DMBA is linked to its oxidative metabolism leading to the development of free radicals, which bind to nucleophilic sites by covalent bonding with cellular macromolecules causing cancerous reactions. Two dosages of $25 \mathrm{mg} / \mathrm{kg}$ and 50 $\mathrm{mg} / \mathrm{kg}$ EACT body weight were used in our research. Doxorubicin was selected as a standard drug that was given as $2 \mathrm{mg} / \mathrm{kg}$, i. p. The result showed that no significant improvements had been made to body weight or organs such as kidney, liver, spleen and heart by animals treated with EACT at any doses administered. In comparison to the DMBA control animals, all of the EACT animals treated significantly reduced the mean volume of the tumor and tumor weight.

Free radicals and their biochemical reactions are part of cancer growth at each metabolic stage. ${ }^{32}$ The previous study shows the effects of herbal polyphenols on cancer, especially on several human cancer cells. ${ }^{33-35}$ Carcinogenesis is known to be associated with oxidative stress mainly by lipid peroxidation. ${ }^{36,37}$ Catalase is widely circulated in all tissues, causing hydrogen peroxide to break down in the tumor cells. Many studies have mentioned that SOD and catalase decreased under various carcinogenic conditions. ${ }^{38}$ Malondialdehyde (MDA), the conclusive outcome of lipid peroxidation was represented to be greater in carcinomatous tissue than in normal tissues. ${ }^{39}$ A raised degree of level of lipid peroxide in control group obviously reflects the overproduction of free radicals and or the failure of the antioxidant protection system to execute sufficiently during the occasion of tumor growth. ${ }^{40}$

In doxorubicin administered groups, the RBC and hemoglobin levels were significantly decreased in comparison with normal control groups. This may have been an immediate consequence of the bone marrow poisonousness of doxorubicin. Tissues can show the degree of oxidative hazard by lipid peroxidation. ${ }^{41}$ The levels of MDA in the breast tissue were measured and the levels were significantly increased in the DMBA control and doxorubicin groups compared to the normal control animals. The alteration in MDA levels in EACT treated groups was not significant when contrasted with normal control. Breast tissue catalase activation in DMBA control and doxorubicin controlled groups was dramatically reduced in comparison with the normal animal group. A high sensitivity free radical present within the body is nitric oxide (NO) which causes malignant growth and genotoxicity. ${ }^{42} \mathrm{NO}$ is especially unstable and can be evaluated by assessing its metabolites such as nitrate and nitrite in physiological fluids or tissues. The nitrate and nitrite levels of the DMBA control groups showing oxidative stress and hence the level was found to be hiked in those groups in our study. In EACT treated groups the levels were found to be near normal. This plant could have been responsible for the scavenging of $\mathrm{NO}$ with antioxidant phytoconstituents.

The breast tissues from the rats treated with standard drug doxorubicin and the tested sample EACT $25 \mathrm{mg} / \mathrm{kg}$ and EACT $50 \mathrm{mg} / \mathrm{kg}$ showed less necrosis and infiltration in a dose depended manner. Some of the typical breast patterns were restored with the EACT treatments. GC-MS analysis confirmed the presence of 2, 4-bis(1phenylethyl)-phenol(39\%) which was found to be the major compound present in EACT. Herbal medicines have been a rich source of various chemotherapy medicines and $C$. thomsoniae may be a likely candidate for cancer.

\section{CONCLUSION}

The current examination presents that EACT could produceinhibitoryoutcomes forDMBA-promptedbreast tumors that might be credited to the phytochemicals present in this plant. The reduction of DMBA induced oxidative stress by EACT could be due to the antioxidant constituents present in it. The GC-MS examination confined the presence of 2, 4-bis(1-phenylethyl)phenol and related substituted compound have been accounted for anticancer impact on breast malignancy in past investigations. Further studies are in progress to separate and illustrate the promising ingredients that contribute to its preventive effects.

\section{ACKNOWLEDGEMENT}

We would like to thank all colleagues for their help.

\section{CONFLICT OF INTEREST}

The authors declare no conflict of interest. 


\section{ABBREVIATIONS}

DMBA: 7,12-dimethylbenz (a) anthracene; MTT: 3-(4,5-dimethylthiazol-2-yl)-2,5-diphenyl tetrazolium bromide; EACT: Ethyl acetate fractions of Clerodendrum thomsoniae Balf.f.; GC-MS: Gas chromatographymass spectrometry; ALT: Alanine transaminase; AST: Aspartate aminotransferase; MDA: Malondialdehyde; NO: Nitric oxide.

\section{REFERENCES}

1. Torre LA, Bray F, Siegel RL, Ferlay J, Lortet-Tieulent J, Jemal A. Global cancer statistics, 2012: Global Cancer Statistics. 2012. CA Cancer J Clin. 2015;65(2):87-108.

2. Wang J, Ye C, Xiong H, Shen Y, Lu Y, Zhou J, et al. Dysregulation of long non-coding RNA in breast cancer: An overview of mechanism and clinical implication. Oncotarget. 2017;8(3):5508-22.

3. Hanahan D, Weinberg RA. Hallmarks of cancer: The next generation. Cell. 2011;144(5):646-74.

4. Welti J, Loges S, Dimmeler S, Carmeliet P. Recent molecular discoveries in angiogenesis and antiangiogenic therapies in cancer. J Clin Invest. 2013;123(8):3190-200.

5. Esquivel-Velázquez M, Ostoa-Saloma P, Palacios-Arreola MI, Nava-Castro KE, Castro JI, Morales-Montor J. The role of cytokines in breast cancer development and progression. J Interferon Cytokine Res. 2015;35(1):1-16.

6. Gullino PM, Pettigrew HM, Grantham FH. N-nitrosomethylurea as mammary gland carcinogen in rats. J Natl Cancer Inst. 1975;54(2):401-14.

7. Wattenberg LW. Chemoprevention of cancer. Prev Med. 1996;25(1):44-5

8. Abba MC, Zhong Y, Lee J, Kil H, Lu Y, Takata Y, et al. DMBA induced mouse mammary tumors display high incidence of activating Pik3caH1047 and loss of function Pten mutations. Oncotarget. 2016;7(39):64289-99.

9. Sharma S, Stutzman JD, Kelloff GJ, Steele VE. Screening of potential chemo preventive agents using biochemical markers of carcinogenesis. Cancer Res. 1994;54(22):5848-55.

10. Anderson ME, Meister A. Transport and direct utilization of gammaglutamylcyst(e)ine for glutathione synthesis. Proc Natl Acad Sci USA. 1983;80(3):707-11.

11. Fossati R, Confalonieri C, Torri V, Ghislandi E, Penna A, Pistotti V, et al. Cytotoxic and hormonal treatment for metastatic breast cancer: A systematic review of published randomized trials involving 31,510 women. J Clin Oncol. 1998;16(10):3439-60.

12. Sun Y. Free radicals, antioxidant enzymes and carcinogenesis. Free Radic Biol Med. 1990;8(6):583-99.

13. Early Breast Cancer Trialists' Collaborative Group (EBCTCG). Effects of chemotherapy and hormonal therapy for early breast cancer on recurrence and 15-year survival: An overview of the randomised trials. Lancet. 2005;365(9472):1687-717.

14. Nounou MI, ElAmrawy F, Ahmed N, Abdelraouf K, Goda S, Syed-Sha-Qhattal H. Breast cancer: Conventional diagnosis and treatment modalities and recent patents and technologies. Breast Cancer. 2015;9(Suppl 2):17-34.

15. ACS. American Cancer Society. In: Cancer Treatment and Survivorship Facts and Figures 2016-2017. Atlanta: American Cancer Society. 2016.

16. Hunt DR, Bailey LH, Bailey EZ. Hortus third. A concise dictionary of plants cultivated in the United States and Canada. Kew Bull. 1978;32(4):801.

17. Schmid R, Riffle RL. The tropical look: An encyclopedia of dramatic landscape plants. Taxon. 1998;47(4):985.

18. Kar P, Chakraborty AK, Bhattacharya M, Mishra T, Sen A. Micro propagation, genetic fidelity assessment and phytochemical studies of Clerodendrum thomsoniae Balf. f. with special reference to its anti-stress properties. Research in Plant Biology [Internet]. TathQeef Scientific Publishing. 2019;09-15.

19. Shoja MH, Reddy ND, Nayak PG, Biswas S, Srinivasan KK, Rao CM. In vitro mechanistic and in vivo anti-tumor studies of Glycosmis pentaphylla (Retz.) DC against breast cancer. J Ethnopharmacol. 2016;186:159-68.
20. Arivazhagan L, SorimuthuPillai S. Tangeretin, a citrus pentamethoxyflavone, exerts cytostatic effect via p53/p21 up-regulation and suppresses metastasis in 7,12-dimethylbenz( $\alpha$ )anthracene-induced rat mammary carcinoma. The Journal of Nutri Biochem. 2014;25(11):1140-53.

21. Miranda KM, Espey MG, Wink DA. A rapid, simple spectrophotometric method for simultaneous detection of nitrate and nitrite. Nitric Oxide. 2001;5(1):62-71.

22. Ohkawa H, Ohishi N, Yagi K. Assay for lipid peroxides in animal tissues by thiobarbituric acid reaction. Anal Biochem. 1979;95(2):351-8.

23. Cohen G, Dembiec D, Marcus J. Measurement of catalase activity in tissue extracts. Anal Biochem. 1970;34(1):30-8.

24. Stimpfel M, Virant-Klun I. Cancer incidence and mortality worldwide: Sources, methods and major patterns in GLOBOCAN 2012. J Cancer Stem Cell Res. 2016;4(3):1.

25. Baskar R, Lee KA, Yeo R, Yeoh K-W. Cancer and radiation therapy: current advances and future directions. Int J Med Sci. 2012;9(3):193-9.

26. Costa I, Solanas M, Escrich E. Histopathologic characterization of mammary neoplastic lesions induced with 7,12 dimethylbenz(alpha)anthracene in the rat: A comparative analysis with human breast tumors. Arch Pathol Lab Med. 2002;126(8):915-27.

27. Barros ACSD, Muranaka ENK, Mori LJ, Pelizon CHT, Iriya K, Giocondo G, et al. Induction of experimental mammary carcinogenesis in rats with 7,12-dimethylbenz(a)anthracene. Rev Hosp Clin. 2004;59(5):257-61.

28. Clarke R. Issues in experimental design and endpoint analysis in the study of experimental cytotoxic agents in vivo in breast cancer and other models. Breast Cancer Res Treat. 1997;46(2-3):255-78.

29. Russo J, Hasan LM, Balogh G, Guo S, Russo IH. Estrogen and its metabolites are carcinogenic agents in human breast epithelial cells. J Steroid Biochem Mol Biol. 2003;87(1):1-25.

30. Balogh GA, Russo IH, Russo J. Mutations in mismatch repair genes are involved in the neoplastic transformation of human breast epithelial cells. Int J Oncol. 2003;23(2):411-9.

31. Flohé L, Ötting F. [10] Superoxide dismutase assays. In: Methods in Enzymology. Elsevier. 1984;105:93-104.

32. Kwon KY, Jang JH, Kwon SY, Cho CH, Oh HK, Kim SP. Cadmium induced acute lung injury and TUNEL expression of apoptosis in respiratory cells. J Korean Med Sci. 2003;18(5):655-62.

33. Haghiac M, Walle T. Quercetin induces necrosis and apoptosis in SCC-9 oral cancer cells. Nutr Cancer. 2005;53(2):220-31.

34. Vidya PR, Senthil MR, Maitreyi S, Ramalingam K, Karunagaran D, Nagini S. The flavonoid quercetin induces cell cycle arrest and mitochondria-mediated apoptosis in human cervical cancer (HeLa) cells through p53 induction and NF-kB inhibition. Eur J Pharmacol. 2010;649(1-3):84-91.

35. Bishayee K, Ghosh S, Mukherjee A, Sadhukhan R, Mondal J, Khuda-Bukhsh AR. Quercetin induces cytochrome-c release and ROS accumulation to promote apoptosis and arrest the cell cycle in $\mathrm{G} 2 / \mathrm{M}$, in cervical carcinoma: Signal cascade and drug-DNA interaction. Cell Proliferation. Wiley. 2013;46(2):153-63.

36. Trush MA, Kensler TW. An overview of the relationship between oxidative stress and chemical carcinogenesis. Free Radical Biology and Medicine.1991;10(3-4):201-9.

37. Rice-Evans $\mathrm{C}$, Burdon R. Free radical-lipid interactions and their pathological consequences. Progress in Lipid Research. 1993;32(1):71-110.

38. Thirunavukkarasu C, Sakthisekaran D. Effect of selenium on $\mathrm{N}$-nitrosodiethylamine-induced multistage hepatocarcinogenesis with reference to lipid peroxidation and enzymic antioxidants. Cell Biochemistry and Function. 2001;19(1):27-35.

39. Yagi K. Lipid peroxides and human diseases. Chemistry and Physics of Lipids. 1987;45(2-4):337-51

40. Vasavi H, Thangaraju M, Sachdanandam P. Effect of a-tocopherol on lipid peroxidation and antioxidant system in fibro sarcoma bearing rats. Molecular and Cellular Biochemistry. 1994;131(2):125-9.

41. Janero DR. Malondialdehyde and thiobarbituric acid-reactivity as diagnostic indices of lipid peroxidation and peroxidative tissue injury. Free Radical Biology and Medicine. 1990;9(6):515-40.

42. Vakkala M, Kahlos K, Lakari E, Pääkkö P, Kinnula V, Soini Y. Inducible nitric oxide synthase expression, apoptosis and angiogenesis in in situ and invasive breast carcinomas. Clin Cancer Res. 2000;6(6):2408-16. 


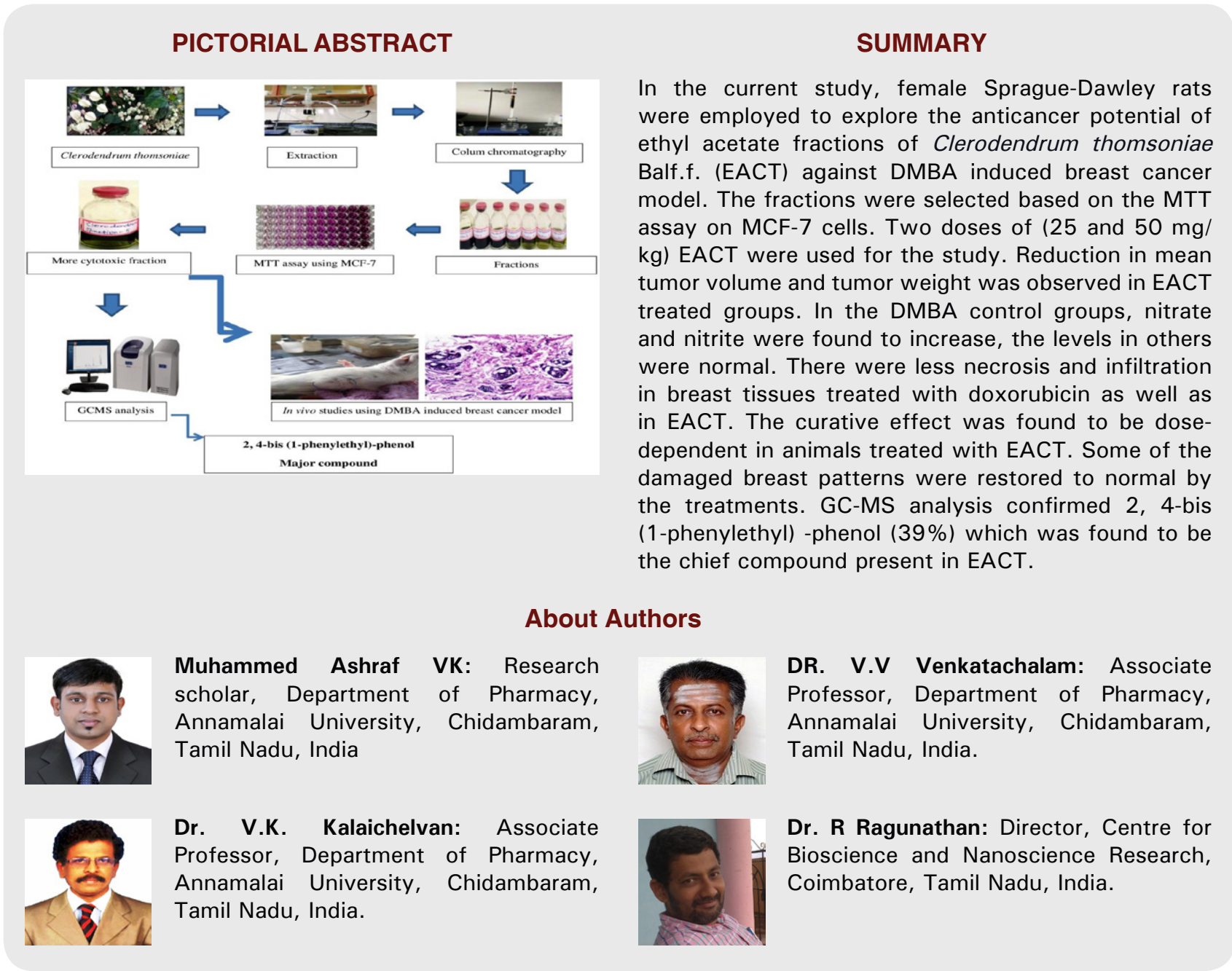

Cite this article: Muhammed Ashraf VK, Kalaichelvan VK, Ragunathan R, Venkatachalam VV. Antiproliferative Potential of Ethyl acetate Extract of Clerodendrum thomsoniae Balf.f. on DMBA-induced Breast cancer in Female Sprague- dawley Rats. Indian J of Pharmaceutical Education and Research. 2021;55(1):205-14. 